\title{
The influence of leadership and motivation work to discipline work teachers in high school
}

\author{
Yohana Sarkol ${ }^{1}$, Happy Fitria ${ }^{2}$, Missriani Missriani ${ }^{2}$ \\ ${ }^{1}$ Sekolah Menengah Atas Patra Mandiri Palembang, Indonesia \\ ${ }^{2}$ Universitas PGRI Palembang, Indonesia
}

\begin{tabular}{l} 
Article Info \\
\hline Article history: \\
Received Jul $8^{\text {th }}, 2021$ \\
Revised Aug $23^{\text {th }}, 2021$ \\
Accepted Aug $30^{\text {th }}, 2021$ \\
\hline
\end{tabular}

\section{Keyword:}

leadership motivation work and discipline of teachers

\begin{abstract}
This study aims to 1 to test the leadership of 1 ) teachers work discipline , 2 ) influence motivation teachers tenure to teachers work discipline, and 3 ) influence leadership and motivation of teachers work in togher teachers work discipline. This study using quantitative methods derived from sources both primary and secondary. Population and a working and motivation of teachers work discipline. The study is done in high school patra independent 01 Palembang .The collection of data using the survey with samples from 36 teachers. The data that has been collected analyzed using descriptive analysis and analysis of multiple regression. The result showed that : (1) is significant influence among schools to head leadership style discipline teacher in high school patra independent 01 Palembang; (2) any impact of the significant work to discipline the teacher in high school patra independent 01 palembang; (3) Significant influence is of a style of leadership
\end{abstract}

(C) 2021 The Authors. Published by IICET.

This is an open access article under the CC BY-NC-SA license (https://creativecommons.org/licenses/by-nc-sa/4.0

\section{Corresponding Author:}

Sarkol, Y.,

Sekolah Menengah Atas Patra Mandiri Palembang, Indonesia

Email: yohanasarkol16@gmail.com

\section{Introduction}

Every man need of education because of education is very important for development of human beings. Through education, men did not just get teaching special skill but also something more in-depth that give knowledge, consideration and wisdom .Education is conscious effort and planned to realize the atmosphere learning and learning that participants students actively develop the potential himself so as to have spiritual power religious, self-control, personality, intelligence, attitude noble, and skills needed himself and the community. Therefore education is capital a basis for Creating human resources. Superior human resources. The world major is. school education, School was one of the education service. AlternativeThe school as an institution of course had a vision, mission the purpose and function of. To all operations, manifesting, vision achieving the objective, and do their job the schools need professionals, management of working and sources organization that supports both financial and non financial

Teachers are one source of human resources improve our be in school. Performance teachers at schools have significant roles in the achievements of the purpose of school. Problems performance interest various parties, government performance be felt by the community and performance of teachers would be felt by students or parents. Various business carried out to achieve a good performance. Attention a government against education been socialized, budget education mandated the act of $20 \%$ commenced. So performance of teachers of course will be attention of all parties. Teachers should really competent and teachers must also be 
able to serve optimally. Performance of teachers who optimal influenced by various factors, both internal and external. Leadership can defined as a skill someone to affect a group toward the achievement of the aims.

The quality of leader often considered as the most important factors determine the success a school. Leader who effective can affect his followers to have optimism greater, confident, as well as the commitment on the objective organization on whom it is determined. This have consequences that each leader obligation to provide are build attention, move, and direct all the potential here teachers in the area that can realize stability school and better performance teachers oriented to the purpose of school. School head leadership can affect teachers ' work and the motivation student learning. Motivation is very important in the on teacher performance. Motivation or individuals for impact on someone involved in the and work that is lead to purpose as satisfaction. Teachers have a strong desire that appear as the effect the kind of in to engage and to partake in schools to do all tasks and works on teachers and sustainably to dedicate self through all tasks and works voluntarily because comfort and the pleasure based on strong motivation.

Besides motivation, a teacher must have special skill, capable of transform information and learning to students. Although teachers are not the only information center in the classroom, it because students must given the chance to developing themselves. The main task of teachers do not only conveying knowledge but fertilize understanding, that students can independent study. The ability to find your own and taught himself considered can be learned [1]. A lot of factors affect performance of teachers, of them are adequate competence, a work environment where safe and sound, a chance to develop knowledge, a sense of belonging , motivation work, discipline work and others [2]. Performance of teachers in addition to being influenced by motivation work, also can be influenced by the discipline of work high. Thus schools that to the learning process grow discipline, will serve as forming the value and norma to their students Attitudes and accountability for teachers, as well as self control.

\section{Method}

The methodology with quantitative is the method to know the specific treatment /. against anotherBut the goal is to test hypotheses [3]. Quantitative variables tested the (X1) (leadership to discipline the teacher (X1) y the teachers work (X2) teachers to work discipline (Y) And the testing of hypotheses together ( simultaneous ) is that leadership ( $\mathrm{x} 1$ ) work and motivation of teachers to work discipline (X2 ) (Y) y so all the data are analyzed in the form of quantitative. The subject of this research is all teachers in high school patra independent 01 Palembang consisting of 32 teachers with the number of teachers who have been permanent teachers, foundation as for the sample used in this research is to use the survey sampling or saturated, sample where is the overall sample. make of it. The sample collection technique in this research is a total. Sampling.

\section{Results and Discussions}

This study was conducted for the purpose of know influence school head leadership and motivation to discipline work teachers work in high school patra which have mandiri palembang 01. Reference to research according before, the formulation can be obtained a problem that school head leadership and motivation influential work in significantly to discipline teachers' tenure.

The research phase aims to know the schools to influence the head leadership senior high school teachers patra which have Mandiri palembang 01. On the outcome before research described, the results problems in research said. Research that leadership menjelasakan school principals have an significantly to discipline teacherswork in high school Patra which have independent research 01 Palembang.variabel X1 influential in significantly to $\mathrm{Y}$ and are positive. Proven from the the regression equation is linear shows of simple constant 10.772 , that is if school head leadership (value of $0, \mathrm{X} 1$ ) teachers ' work and discipline positive 10,772 value which is then the regression coefficient school head leadership of 0,889 . The was positive in value which there was a positive relationship between the school principal discipline leadership teachers ' work.

The leadership of the school has the effect on head teachers' work diisiplin high school patra mandiri 01 Palembang. Of school principals as capable of cultivating leader must discipline the teachers with using rule as an instrument to enforce discipline. Of school principals in enforce discipline in school has a different way between leaders of each other. In line with the opinions of [4] define leadership is the way used in the process leadership that implemented in behavior leadership someone to influence others to act in accordance with what she wants. The better leadership of school principals who applied then it would be more good too the discipline of a high school teacher Patra Mandiri 01 Palembang 
Influence motivation work (X2) of discipline teachers (Y)

Research aims to understand the motivation to influence work teachers in of a high school teacher Patra Mandiri 01 Palembang. Research before work in show have leverage the motivation to teachers of a high school teacher Patra Mandiri 01 Palembang, said penelitian.dapat so they are problems seen pada tabel 4.18, revealed the double correlation $(\mathrm{r})$ of 0,495 , the correlation between work and motivation $(\mathrm{x})$ on variables $(\mathrm{Y})$ of the 0,495 . Because the value of double correlation is between $0,40<0,599$, have inferred there was a between $\mathrm{X}$ to $\mathrm{Y}$. Guru will work with vigorous and more disciplined, when having high motivation work. Motivation influenced by various factors such teachers ' work, both internally and externally. One of factors affect motivation are the needs of teachers ' work in him These needs and encouraged them to do it. According to Uno (2015: 71 ) teachers work motivation is nothing but a process carried out to raise teachers so that their behavior could focus on real efforts to achieve its intended purpose.

Influence school head leadership (X1) and motivation to work (X) the teachers (Y)

In this research have aims to know influence school head leadership and motivation to work the senior high school teachers patra which have mandiri Palembang 01. Based on the research explained previously, the results was a problems research research for the school head leadership and motivation to work the school teachers in high school patra which have mandiri Palembang 01 research shows that double correlation $(\mathrm{r})$ of 0,832 shows and the correlation between school head leadership (X1) and motivation (X) on variables (Y) of the 0,832 , so it can be concluded there was a very strong between $\mathrm{X} 1$ and he $\mathrm{x}$ to.Variable school head leadership ( $\mathrm{x} 1$ work ) and motivation ( $\mathrm{x}$ ) have an significant work on variables discipline (Y) despite having a very strong. Of the research results show schools to discipline head leadership teachers ' work of $\% 67,7$ give contribution. Can be expressed any impact significant head leadership discipline between schools to teachers ' work in high school Patra which have Mandiri Palembang 01. And, the percentage variable influence contributions motivation to teachers work the impact of $24,5 \%$. That is significant influence work between the motivation to teachers in high school Patra which have Mandiri Palembang 01. Head leadership so it can be concluded that schools providing more influence to discipline teachers ' work in high school Patra which have Mandiri Palembang 01 compare work with the motivation. Thus, head leadership is influence and motivation to work the school teachers in high school Patra which have Mandiri Palembang 01. It supported by according theories before.Better school head leadership is applied and the higher motivation work owned, also discipline would affect on the teachers ' work.

\section{Conclusions}

Based on the research through, data analysis testing the hypothesis and the outline presented, so can be taken some: concludes that there are significant influence between the leadership of the principal (X1) to discipline the teacher (Y). Proved to be going on a relationship that is between the leadership of the principal (X1) to discipline the teacher $(\mathrm{Y})$ with an $\mathrm{r} 0,822$, as much as because the value of the correlation between $0,8-1,000$, double very strong. Of the equation linear regression simple obtained a coefficient that are positive that is a positive relationship between variables the leadership of the principal (X1) with discipline teacher (Y), increasing the leadership of the principal the increased as well work discipline in high school teacher patra independent 01 Palembang. That, variable leadership principal as an independent variable 1 give the effect on teacher $25,3 \%$, discipline as much as proven by the value of the coefficients determined (R2) who shows a figure 0,676 Or $\%$ 67,6. Penelitian was conducted in high school mandiri patra which have Palembang 01. Use the survey data collection from as many as 36 teachers. The data that has been collected analyzed using descriptive analysis and regression analysis double.

\section{References}

Nasution. 2010. Berbagai Pendekatan dalam Proses Belajar dan Mengajar. Jakarta: Bumi Aksara. Supardi. 2014. Kinerja Guru. Jakarta: PT Raja Grafindo Persada Sugiyono. 2013. Metode Penelitian Kombinasi (Mixed Methods). Bandung: Alfabeta. Rusdiana A, Kebijakan Pendidikan ( dari Filosofi ke Implementasi), Bandung : Pustaka Setia, 2015. 
